\title{
Restructuring the Teacher Education System in Vietnam
}

\author{
Quang Hong Pham \\ Thai Nguyen University, \\ Thai Nguyen, 250000, Vietnam \\ Nam Danh Nguyen* \\ Thai Nguyen University of Education, \\ Thai Nguyen, 250000, Vietnam
}

\begin{abstract}
This paper presents international experiences and the real situation of the teacher education system in Vietnam. This research has also shown some challenges that teacher education institutions would face within the context of radical and comprehensive education renovation. Based on analyzing the teacher education system and teacher education management, the paper presents some viewpoints and principles for restructuring teacher education as well as draws lessons for Vietnam in renovating the teacher education model. Then, the paper proposes the new teacher education model and reorganized the teacher education system, in which the research determines some key educational universities and their "satellites" educational universities and colleges at localities across the country. The paper also suggests a solution for establishing the connection between key educational universities and their satellites among the system so that it could meet the requirements of the labor market and society. These suggestions help educational universities and colleges to reorganize their functions and missions of training future teachers. The research also makes a contribution to change the policies for teachers and teacher education in Vietnam.
\end{abstract}

Keywords: restructuring; teacher education; teacher education system; teacher training; educational university; Vietnam

\section{Introduction}

In the trend of globalization, teachers must work in a multicultural, multi-ethnic, multi-religious, multinational, and multi-lingual environment. This trend requires teachers must not only meet the national professional standards but also towards the international professional standards to be able to adapt to this

* Corresponding author's e-mail: danhnam.nguyen@tnue.edu.vn 
working environment. That is also the challenge to train global citizens to adapt to the world labor market (Quang, 2013; Binh, 2013; Ayesha, 2018). Therefore, the impact of international integration trends on the professional standards of teachers is a matter of concern in the process of teacher training. Furthermore, the teacher labor market in the globalization trend is broad, open, and flexible. Hence, if the teacher does not meet the requirements of international standards, there is a risk of being unemployed (Sang, 2011; Quang, 2013; Michael, 2018). Consequently, teacher training or educational universities must train teachers who have the competencies to adapt to the international working environment.

Vietnam has faced with an urgent need for industrialization and modernization in the context of a socialist-oriented market economy and global integration. The government has been implementing a radical and comprehensive renovation in education and training. In particular, the general education program in the year 2018 has crucial changes from educational objectives, learning content, methods to evaluation methods, implementation conditions, and management systems. Therefore, it is very necessary to renovate the teacher education system to train a new model of teachers that satisfies the educational renovation (Binh, 2013; Quang, 2013). The search for teacher training models suitable for the new context which is conducted with a series of workshops on teacher education. Moreover, the Ministry of Education and Training has developed teacher standards, school standards, and requested educational universities to renew training programs, program, and institution accreditation. In this circumstance, the paper studies the experiences of successful institutions in the world in teacher education. It draws lessons for Vietnamese higher education for determining the direction in modernizing teacher training models.

International studies have shown that teacher education programs in many countries have gradually developed from low-ranked teacher training institutions to comprehensive universities. In Vietnam, the educational colleges trained preschool, elementary school teachers, and educational universities trained high school teachers. These institutions are being upgraded into multidisciplinary universities to meet the growing needs for high-quality teachers. Besides, educational schools and teacher training colleges integrated into universities, and non-teacher universities are allowed to involve in teacher preparation (Quang, 2013; Binh, 2013; Hieu, Nam, 2019). Reconstruction of teacher education programs aims at establishing a new teacher education model at universities where a college of education collaborates with other academic colleges to educate prospective teachers. The system formed by teacher training colleges and local educational universities that respectively trained prospective teachers for preschools, elementary schools, and secondary schools. In Vietnam, teacher training colleges and educational universities were public, managed by, the model of the central planning economy. The resources, recruitment of faculty and enrolment of students, approaches of teacher education, and allocation of graduates were all decided and controlled by the Ministry of Education and Training. The objective of this study is to investigate the real situation in the teacher education system in some countries in the world and to evaluate the system in Vietnam. After that, the study draws lessons for teacher education and suggestions for restructuring the teacher education system in Vietnam that 
satisfying the needs of the labor market, society, and international cooperation in higher education.

\section{Literature review}

\subsection{Teacher education management}

The traditional teacher education system transformed into a new direction. Teacher education programs did not solely retain in educational colleges and universities; instead, more and more comprehensive colleges involved in preparing teachers (Christie, Drew, 2017; James, 2018). The expansion of teacher education programs into comprehensive colleges and universities is the most radical change in the institutional structure of teacher education in the world. But this kind of change has a limited impact on the teacher education system as the majority of teachers who are still trained in teacher education colleges and universities in Vietnam. Therefore, locating teacher education programs in comprehensive universities will be the long-run goal for the reform of teacher education (Sang, 2011; Quang, 2013). In many countries, teacher education follows the market mechanism, according to the needs of the labor market. However, because of the unique nature of each country, there are differences in the role and intervention of the government in the teacher education system (Susan, 2015; Saba et al., 2020). There is still centralized management of teacher education systems such as South Korea, Singapore, France, Netherlands, England, China, Japan, Hong Kong, etc. The Ministry of Education manages almost all aspects of the teacher education process and diplomas or certificates for teachers (Vidovich, 2008; Adele, 2009; Cheryl, 2016).

In South Korea, the main task of training teachers is from the universities of education and the faculties of education in comprehensive universities. In the past, too constricted regulations and deep government intervention prevented the Korean education system from meeting the educational needs of the people. Therefore, South Korea has reformed its education system towards a marketbased approach (Lee, 2000). In Singapore, the top-down management model is applied uniformly in education. The Ministry of Education jointly researches the problem of identifying human resource training needs for society and the development trend of industries serving the requirements of economic development, the Ministry of Manpower, and the Economic Development Council, and then make recommendations to the universities. Therefore, education policies effectively integrated with economic systems and human resource training orientations (Cheryl, 2016; Oon-Seng, Woon-Chia \& Ee-Ling, 2017).

In the Netherlands, the Ministry of Education and the Education Inspectorate are responsible for state management of teacher training. The Ministry provides guidelines, regulations, and guidelines to implement the requirements for enrollment admission, output standards, and the content of teacher training programs. In the United Kingdom, the Department of Teacher Training, the Department of Education and Skills, the Education Standards and Teaching Council are responsible for training and issuing certificates for teachers (Sun, 2004; Cheryl, 2016). Besides, these institutions are also responsible for 
developing and issuing regulations on training and certification for teachers, including a set of standards for testing teacher training programs, requirements for early enrollment, input and output criteria, the content of teacher certification exams, and teacher training programs.

In China, the teacher education system consists of 141 educational or "normal" schools, including 37 educational universities. There are three types of independent teacher training, namely: teacher education school, educational school (including teacher training school), and vocational-technical schools. Teacher education schools divided into educational universities, educational institutes (colleges), and high schools. The educational schools divided into senior national executive education institutes, provincial educational institutes, regional city-level education institutes, district teacher training schools. Besides, China has several multidisciplinary universities that also participate in teacher training. The management of teacher training is in the form of a limited right system, which means that the central government decides the development of the teacher training system. Under state leadership, education authorities at all levels directly manage the respective teacher training schools in the areas of human resources, finance, and facilities (Paine, Fang \& Wilson, 2006). Currently, the Ministry of Education retains control of a small number of schools (less than $5 \%$ of the total number of universities and colleges), most of which are heavily financially invested with the intention to become "world-class university". Other universities are financially funded and directly under provincial or municipal governments or special zones. Generally, Chinese teacher training characterized by an independent orientation-training model, organized and managed by the State. The local government directly manages and supervises the direction of educational organization, the structure of training majors and subjects, personnel, enrollment, program content, financial allocation, etc. This article helps the autonomy of educational schools increased significantly. Besides, the Chinese government encourages comprehensive universities and technical universities of good quality to participate in training primary and secondary teachers. The advantage of comprehensive universities in general in teacher training is to provide schools with excellent students, after being trained in pedagogical skills for one to two years to become teachers (Paine, Fang \& Wilson, 2006; Zhu, Han, 2006; Oon-Seng, Woon-Chia \& Ee-Ling, 2017).

Some countries have made full autonomy to higher education institutions in training teachers such as the United States, Germany, Australia, Finland, etc. Recruitment, training, and fostering teachers in many countries based on the standardization principle, in which the most crucial standard is the teacher career standard. Moreover, professional standards for teachers are issued and managed by the government. Countries like the United States, Germany, and Australia, these standards are assigned to the states to regulate. Educational schools determine the content of the training program, but it must be assessed and accredited by an independent national body or state inspection committee. Therefore, universities, regardless of whether they are public or private, have autonomy. The states authorize professional associations to develop professional standards for teachers and oversee training schools according to the approved standards. Thus, the United States, Germany, and Australia have a socio- 
economy operating on the principles of a market economy, law, democracy, and multiculturalism (Sun, 2004; Paul, 2015; Cheryl, 2016; Christie, Drew, 2017).

In Australia, until before the late 1980s, the Australian post-secondary education system consisted of two sub-systems: a group of higher education institutions and a group of colleges, including technical and educational colleges. However, since the early 1980s, there have been many factors that require the integration of colleges into universities. Specifically, the demand for teacher training has been saturated, which makes it difficult for educational colleges to recruit students. State budget spreads over many inefficient schools. Many colleges are small in size that do not create conditions for faculty members to improve their teaching and applied research capacity. In 1988, the Australian government proposed a new policy (White Paper) to restructure the higher education system. The scheme identifies the merger requirement to reduce the number of universities and colleges but increases the training scale of facilities. Educational colleges forced to merge or convert into universities to strengthen management and investment efficiency (Paul, 2015; Susan, 2015).

In the United States, the national center for education statistics tasked with making teacher demand forecasts. Some states also research and apply their forecasting model. The model predicts the total number of new teachers that need to be recruited based on the time series because teachers retired gradually year by year and other reasons, as well as the increase of students enrolling. The model uses the national center's educational statistics data from school surveys, social human resource surveys, and other sources. In New Zealand, the teacher replacement demand forecast focuses on understanding the factors that affect the estimates of the number of teachers for the new school year to meet the needs of schools (Paul, 2015; Cheryl, 2016; John, Mary, 2016). These factors include the rate of transfer of students to the next level of education, the demand for teachers, policy changes, the ratio of teachers/students, the teacher's class time, and the age of the teacher.

\subsection{Restructuring the teacher education system}

In China, the first teacher training facility established in 1897, which is Nanyang Gongxe Public School in Shanghai, later Jiaotong University. Next was Jinshi Daxuetang in 1898, then the Beijing University. In 1904, the first public educational school was established. In the early stage, the Chinese educational model is similar to the Japanese educational model from enrollment, program content, training time and objectives. After that, the Chinese teacher training system shifted to the French model. The training facilities are divided into two levels, medium, and high quality, aiming to train primary and secondary teachers. These schools later turned into educational schools. By 1920, there was a significant change in modern Chinese society. The teacher training system was learning from the Western model, especially the United States. In 1922, the public school system changed to a six-three-three model similar to that of the United States (six years of elementary school, three years of junior high school, and three years of high school). The training of teachers is also diverse with more models such as educational schools, specialized teacher training schools, educational colleges and educational universities with the goal of training teachers at the different levels of school (Paine, Fang \& Wilson, 2006; Robyn et 
al., 2017). At present, China has about 120 universities and colleges with teacher training programs, including six key educational universities, 32 provincial educational universities, educational faculties of interdisciplinary universities, and other educational colleges. Key educational universities are identified based on the tradition of research training, the quality of training, and the distribution of six regions of China without any specific set of standards. These key educational universities receive investment and budget support from the Ministry of Education, and other educational universities only receive support from the provinces or localities according to different levels. The function of the key educational universities is to focus on training masters and doctors with minimal training of bachelor. These universities are also different from the provincial educational universities that focus on bachelor training. In summary, there are five approaches to changing the institutional structure of teacher education that have emerged in China. The first approach is that selective teacher training or "normal" universities are changing from institutes preparing teachers to comprehensive universities. Some national selective educational universities transformed into comprehensive universities by expanding the scope of their programs, such as establishing law programs and schools of business. Some colleges combine to form a new educational university. The second approach is that municipal educational schools, two- or three-year teacher colleges, institutes of education, and teacher training schools incorporated into four-year teacher colleges. Thirdly, some educational schools, two- or three-year teacher colleges, institutes of education, teacher training schools, and vocational colleges combined to become three-year comprehensive colleges. Fourthly, some teacher colleges incorporate other kinds of colleges to become universities. The last approach is to establish four-year colleges by merging local and provincial four-year teacher colleges, two- or three-year teacher colleges, and institutes of education (Sun, 2004; Zhu, Han, 2006).

In France, institutions of higher education and teacher training are subject to the state and organizational administration of the Ministry of Education (manages high school levels) and the Ministry of Higher Education \& Research (manages faculty, teacher, and research training). In 1989, France transformed teacher training from a network of educational universities to teacher training institutes. By 2008, these institutes transformed into faculties of teacher training at universities. However, universities are not allowed to recruit and pay salaries for their teachers and staff. Thus, the over-centralized management of the state, leading to the lack of autonomy of training institutions, is one of the main characteristics of the French education system (Cheryl, 2016; Eija, Raimo, 2017; Rita, 2019).

In Australia, it has also experienced a boom in teacher training facilities in the first half of the twentieth century in the context of a series of public high schools, the demand for high school teachers increased. In 1970, the government established and invested in teacher training colleges, creating a two-level teacher training system: colleges and universities. The differences between teacher training colleges and universities are: firstly, college lecturers have lower salaries and do fewer scientific research; secondly, the teacher training program in colleges towards the nature of vocational training; thirdly, colleges train only preschool and primary teachers. By 1988, to improve the quality of teacher 
training, the Ministry of Labor, Education \& Training had made significant decisions on Australian higher education, directly impacting teacher training. Some teacher training colleges have evolved into teacher training universities, with the training period increasing from three years to four years (Paul, 2015). A part of lecturers at educational colleges is moving to work at educational universities. With this reform, teachers' training costs at educational schools partly funded by student tuition fees and a large portion of government funding. Teacher students are preferential with tuition policy, and the time to pay is after graduation, going to work. In 2006, teacher training programs extensively accredited across Australia, the results of which were the basis for the Australian government to invest its budget. The Australian government focuses on attracting excellent graduates to follow the teacher education path with additional time of training. The Ministry of Education takes responsibility for developing national standards for teachers, enrolling teacher students, and improving the quality of data on teacher human resources. In 2011, Australia promulgated a set of professional standards for teachers applicable to teachers nationwide. Since 2012, teacher training programs have focused more on pedagogical practice for students, with internships lasting from 12 to 20 weeks. At the same time, the Government supports educational universities to develop their expertise in teaching pedagogical practice. All Australian teacher training colleges have educational experts who guide teachers in secondary schools (Adele, 2009; Paul, 2015; Jean, Anja \& Clare, 2019).

\section{Research methods}

To investigate the real situation of the teacher education system in Vietnam, a survey was conducted in more than 20 universities and colleges of education from December 2018 to December 2019. A questionnaire designed to examine the restructuring of the teacher education institution system in the context of radical and comprehensive education renovation. Additionally, more than 20 workshops and academic forums also organized to collect lecturers' and specialists' ideas about some measures to reorganize the teacher education system at some localities. In-depth interviews with 60 educational experts also recorded and analyzed to evaluate the training competency of teacher education institutions. As a result, some recommendations in this study based on these experts' points of view. The study also examined international experiences from developed countries to suggest a teacher education model for Vietnam as well as the solutions for restructuring the teacher education system for the whole country.

\section{Research results}

\subsection{The teacher education system in Vietnam}

This study has conducted a survey and analysis of data in the last five years of more than 20 teacher education institutions across the country to assess the status of system restructuring, which focuses on analyzing distribution, organization, resources, scale, and quality of these universities of education in 
the system. From that, we propose the orientation of reorganizing these universities and developing some key educational universities in Vietnam.

There are 114 teacher education institutions, including educational universities, educational colleges, faculties of education in comprehensive universities, and 40 multi-disciplinary vocational training schools for training preschool teachers. These institutions are distributed in all regions and localities $(\mathrm{Lu}, \mathrm{Anh}$, Van, 2019). Each province has at least one pedagogy school, primarily concentrated in some big cities like Hanoi and Ho Chi Minh City. In the period from the late 1990s to the early 2000s, the scale of teacher training institutions was expanded mainly based on establishing faculties of education in multidisciplinary universities, and many educational colleges were upgraded to comprehensive universities but maintaining teacher training program. Consequently, the system of teacher training is too widely distributed, resources scattered, and many educational universities are small in size and low in quality. Most educational universities are entirely independent in teacher training tasks, weak connectivity in the system, no sharing of resources to improve the quality and effectiveness of teacher training for the whole industry.

The training functions of many teacher training institutions are overlapping because there is no specific assignment of tasks for each university in the system. Also, the opening of many pedagogical training disciplines still relies on the available competencies and experience. In some universities, there are faculties of training that coincide with the critical training tasks of other educational universities that wasting investment resources. In particular, there is no connection between educational universities and localities. In other words, there is no link chain of supply and demand for teachers which leads to an excess or partial shortage of teachers. This is one of the emerging issues in recent years that dramatically affects the quality of education in many localities and causes pressing public opinion. Although the educational universities have increasingly focused on the quality of training the training program is not consistent, the output standards have not oriented towards developing students' competencies, not yet closely linked with professional standards teacher requirements. Many students do not find suitable jobs after their graduation, even there is a shortage of local teachers. This fact makes the society, especially students and parents concerned, in many localities the lack of pedagogical enrollment sources and the failure to attract good pupils at schools who are suitable for studying in the teacher education program.

Moreover, quality assurance conditions, training capacity, and scientific research capacity of educational universities are still limited. Professional qualifications of lecturers have not yet met the requirements of training and renovating general education and training. Teaching and scientific research are the two main tasks of lecturers who are parallel and mutually related. The percentage of lecturers with doctoral degrees in many educational universities is not high, especially the universities with small training scale. Most professors, associate professors, and doctors concentrated in educational universities in big cities like Hanoi National University of Education (55.9\% of lecturers with a doctorate), Hue University of Education (49.6\% of lecturers with a doctorate), Thai Nguyen University of Education ( $48.5 \%$ of lecturers with a doctorate). The educational 
colleges in some localities lack qualified lecturers; the percentage of lecturers with doctoral degrees is only more than $4.0 \%$. It expected that by 2022 these universities will reach the rate of lecturers with a doctorate of $60 \%$. With favorable conditions for highly qualified staff, some educational universities may focus on investing in building high-quality training programs. In many educational universities, equipment for teaching and learning is too outdated or has exploited for a long time, so it does not meet the requirements of applying modern technology in education, especially in the context of the fourth industrial revolution. Some educational colleges upgrade to universities or switch to multidisciplinary training in the condition that they have not invested in teaching facilities.

All of the educational institutions in Vietnam are public. Therefore, the revenue of these institutions mainly based on the tuition subsidies provided by the state per student, so the ability to develop and mobilize off-budget financial resources is limited. Although nearly all educational universities have expanded into training fields other than teacher training (multidisciplinary), funding is still primarily based on the state budget. In recent years, the scale of the practice of educational universities and colleges has decreased due to saturated teacher training demand, resulting in low investment and economic efficiency. As such, it is necessary to rearrange the network of educational institutions to focus resources, increase investment in physical and financial facilities to promote effectiveness for the whole system. The scientific research capacity of most educational universities and colleges is weak, failing to meet the requirements of teacher training and education science development. Currently, the new educational universities focus on the task of short-term training and retraining, not paying adequate attention to scientific research. There is no educational university with a robust research group to strengthen research capacity in educational science, develop general education programs, and consult policy mechanisms for implementing new public education at schools.

When the socio-economic transition from a centralized mechanism, subsidy to a market mechanism with macro-regulation, teacher education universities must also have corresponding changes, the higher education system must undertake the training of human resources not only for the State but also for many other economic sectors. Training in order-based human resources, most training products need to be highly adaptable to the labor market. Training human resources for general education is also in the general trend of higher education. If teacher training conducted according to the ordering mechanism, teacher students after graduation will have to be assigned to work. Therefore, it can see that the teacher training sector must adapt to the development of a market economy. However, the scale of teacher training is unique because it will change after a certain period due to reasons such as retired teachers, changes in population size, renovation of education, and training with teacher policies. Therefore, forecasting research on the need for training human resources for learning is an urgent requirement to restructure the network of educational universities.

The education sector lacks predictive capacity in the supply and demand of human resources to meet the needs of the labor market. Educational universities 
(especially local ones) enroll mainly on their training capacity but do not base on the human resource needs of education, locality, and general integration conditions. The increase of the training scale in some universities leads to the difference between supply and demand teachers. Consequently, the students are unable to find jobs after graduation. This situation also causes anxiety for parents and students as well as has not attracted good candidates for admission to educational universities as expected. Moreover, the lack of control of teacherstudent enrollment at some educational universities leads to a waste of state budget allocations. As a result, tuition compensation in teacher training institutions such as Hanoi National University of Education, Ho Chi Minh City Pedagogical University, has a minimal investment. If teachers trained in a closed model, it is necessary to set up the order mechanism of the State, local needs, or other stakeholders. However, the current recruitment of teachers in localities is undertaken by the Department of Interior Office according to the current regulations on decentralization. At the same time, the Department of Education and Training is the unit that manages and employs teachers. Therefore, choosing the method of training teachers according to the ordering mechanism should consider adjusting policies at a macro level. Besides, local education management agencies and teacher training institutions have not been proactive in forecasting the industry's labor supply and demand to suit the population size, population distribution, characteristics of geography, economy-society of the region. The subsidy of teacher education tuition subsidies per student has led universities to try to increase training targets to increase financial resources according to their training capacity leading to the phenomenon of a partial shortage of teachers in some subjects. Therefore, it is necessary to create mechanisms to enhance the autonomy and accountability of educational universities, helping teacher training institutions to promote their dynamism, creativity, innovation, and autonomy. For that reason, the teacher training institutions system should be restructured based on the needs of the labor market through the choices of learners and society.

\subsection{Viewpoints and principles for restructuring teacher education system}

Based on the analysis of limitations and inadequacies of the teacher education system and the educational experts' opinion, this study proposes some viewpoints for restructuring the teacher education system. Firstly, restructuring of the teacher education system should base on quality standards and quality assurance conditions. It creates the classification and mechanism of healthy competition on quality among teacher education institutions, administration innovation, training capacity building, and policies on teacher training. The training must be associated with the needs of teachers in each locality and the requirements of the curriculum. Secondly, overcoming the overlap, inefficiencies of the current teacher education system; ensuring autonomy and accountability, especially accountability for training quality; maximizing the available resources of each institution to form a practical teacher education network; investing on setting up some key educational universities with the role of leading the system; and transforming some other educational universities and colleges into "satellites" of the key educational universities in regions. Thirdly, the implementation of arrangement needs an appropriate, inherited, and feasible roadmap, so that teacher education institutions have enough time to reorganize 
themselves. Restructuring should also pay attention to the distribution of educational universities by geographical space to ensure regional factors, suitable to population size, socio-economic development of the region, and each locality. Finally, the State should play a central management role in the field of teacher education, promote socialization, mobilize and effectively use all resources invested in education; strengthen interconnection between the educational universities and the labor market in the training process; enhancing the responsibilities of supervision of the Ministry of Education and Training.

Based on those basic viewpoints, this study proposes some principles for restructuring teacher education system. Firstly, the restructuring must be based on a set of educational university regulations, creating conditions for ensuring the quality of education and improving the efficiency of the global education system. The Ministry of Education and Training needs to develop a set of educational university standards, and then evaluate the training capacity according to these standards to identify key or "satellite" teacher education institutions. It is necessary to determine the functions and roles of the key educational universities and their satellites in the system. The key educational universities must play a leading role in the system, improving the effectiveness and quality of teacher education throughout the country. Secondly, restructuring of educational universities must take into account geopolitical, socio-economic, and regional factors. The consideration of geopolitical factors aimed at stimulating the steady development among regions, creating favorable conditions not only in the teacher training process but also teachers' continuous professional development. It is crucial to develop the key teacher education institutions in big cities as well as to distribute teacher education institutions in regions, especially in the mountainous and remote areas. This distribution creates favorable conditions for students and recruit teachers for localities. Thirdly, restructuring the teacher education system should take into account the context of basic and comprehensive renovation in education and training, the meaning of international integration, the new trend in the world in teacher education, and the change in personality model of future teachers. To successfully implement the new general education program requires educational universities to restructure, renovate curriculum and training models following the national qualification framework and Association of Southeast Asian Nations qualification framework. Some researches have shown that educational universities tend to become multidisciplinary universities and educational colleges upgrade into comprehensive universities (John, Mary, 2016; Christie, Drew, 2017; Michael, 2018). The need for the number of teachers is no longer urgent, even redundant. Still, the professional quality requirements of the teachers are critical to meet the global integration and general education renovation as well. Therefore, the system needs to ensure the interconnection among key educational universities, multidisciplinary universities, and educational colleges at localities. Fourthly, the teacher training model needs to meet the requirement of using the teacher force of society, paying attention to the "market areas" factor, the attractiveness and the spread of key educational universities. Besides, ensuring the requirements of teacher training according to practical needs to serve private schools, international schools in the country, 
from which it is necessary to orient the supply of teachers for the regional and global labor market.

\subsection{Lessons for restructuring teacher education system}

Over the past decade, many notable positive changes have occurred in teacher education systems in many countries around the world. In Vietnam, there are following challenges that teacher education system would face with: (i) a diverse society in the process of stable economic development; (ii) the relationship between government, society, and teacher education institutions; changes in the governance role of government; significant differences between the quality of teachers in urban and rural areas; (iii) inheritance or innovation in teacher education change in which educational universities tend to be multidisciplinary and research-oriented; (iv) the reform of teacher education influenced by the globalization and the context of international teaching staff.

There are several educational universities and colleges that are psychologically waiting for a change in the State's investment and remedy policies for teacher education but are not ready to renew themselves. Hence, restructuring the teacher education system help overcome the dispersion, spreading, and duplication of functions of the current system, linking training with user needs, focusing on quality and efficiency of the training process, ensuring inheritance, feasibility, promoting self-control and accountability of educational universities. However, this study would not present a detailed solution for reorganizing the teacher education system as well as social impact after restructuring. To implement this task, the government should encourage educational universities or colleges to voluntarily merge or join by the law to focus resources, improve the quality and effectiveness of training. Educational universities and colleges that overlap in terms of their functions in the same locality must have a roadmap to merge into one teacher education institution or change into local educational service centers.

From analyzing the above challenges, this study draws lessons for restructuring teacher education system in Vietnam. The Ministry of Education and Training has centralized management of teacher training, but it needs to give more autonomy to educational universities. The Ministry only manages at the macro level like issuing educational policies, professional standards for teachers, teacher education program standards, output standards, and program accreditation standards. It should establish some key educational universities under the direct management of the Ministry of Education and Training, allowing them to conduct multidisciplinary training and also allowing comprehensive universities to open a new teacher education program. The government focuses on investing resources for key educational universities to train high-quality teachers and meet international teacher education standards. It is also necessary to maintain teacher education institutions in localities, especially in regions with typical cultural characteristics and areas of ethnic minorities. However, it needs to merge teacher education institutions in the same location, allowing teachers to be trained at provincial colleges (to train local preschool teachers and to be continuing education centers for fostering local teachers and educational managers). The key educational universities take the responsibility to train high-quality teachers and foster core teachers and 
educational managers at the localities. Finally, it should build close relationships between educational universities and their satellites, schools, and society in teacher training and fostering, educational scientific research, and providing educational services for the community. To build this relationship, it is necessary to clearly determine the functions and roles of key universities and universities, colleges at the localities. Specifically, the key education universities must focus on high-quality teachers and post-graduate training. Satellites universities and colleges must focus on developing bachelor programs, training and re-training teachers for localities.

\section{Conclusions}

In some developed countries, the educational universities built, and the organizational structure is in comprehensive universities. In Vietnam, most localities have teacher education institutions from colleges to universities. Therefore, the higher education master plan and data on human resource needs for the industry will help key educational universities and colleges at the localities to determine the training scale. Also, it is necessary to develop an orientation to enhance the efficiency of investment, improve the quality of graduates, and propose practical teacher training and fostering solutions to make the network of educational universities effective and sustainable. On the one hand, it is also crucial to establish some key educational universities to concentrate investment resources to enhance the quality of teaching staff at schools. On the other hand, it acts as a focal point to connect "satellites" educational universities/colleges in localities to perform the tasks of fostering teachers and educational managers.

In general, firstly, it should strengthen the network of teacher education institutions based on stratification by level, type of training, and socio-economic characteristics of each region. Secondly, it should decentralize the management of teacher education institutions to promote autonomy, creativity, and selfresponsibility in teacher training. Thirdly, it is necessary to support scientific research projects, especially educational sciences in educational universities. Fourthly, the investment in facilities for educational universities must be associated with capacity training for staff and lecturers of these institutions to limit wasteful expenditure. Smart classroom/lab models can invest efficiently, but performance is also an issue that needs to address. Fifthly, to restructure a network of teacher education bases on a socialist-oriented market economy, that is, both ensure the autonomy of educational universities and ensure uniformity in administration. In other words, restructuring the teacher education system must be combined with renovating university administration and enhancing training capacity on teacher education.

\section{Acknowledgments}

This paper supported by a research grant from the National Educational Science Program code KHGD/16-20 with the study "Research on restructuring the network of teacher training institutions in Vietnam to 2025, vision to 2035". 


\section{References}

Adele, G. (2009). Restructuring teacher education. Issues in Education Policy, 6, Centre for Education Policy Development.

Ayesha, B. (2018). Teacher development and teacher education in developing countries: On becoming and being a teacher. Palgrave Macmillan. DOI:10.1057/978-1-349-95363-9

Barbara, L. B. (2015). Restructuring teacher education in the united states: finding the tipping point. Athens Journal of Education, 2(4), 297-312.

Binh, T. N. (2013). Research on proposing some measures of renovation in training and fostering teachers. Research Project at National Level, Vietnam Peace, and Development Foundation.

Chen, Y., \& Zhu, Y. (2003). Teacher Education Research. East China Normal University Press.

Cheryl, J. C. (2016). Structure of teacher education. In J. Loughran, M.L. Hamilton (eds), International Handbook of Teacher Education, (pp. 69-135), Springer.

Christie, M., \& Drew, P. (2017). Handbook of research on teacher education and professional development. IGI Global.

Eija, K., \& Raimo, N. (2017). Reforming teaching and teacher education: Bright prospects for active schools. SensePublishers. DOI:10.1007/978-94-6300-917-1

Hieu, T. L., \& Nam, D. N. (2019). The teacher's competence of integrated teaching at primary school science. Journal of Physics: Conference Series, 1340, 012023, IOP Publishing. DOI:10.1088/1742-6596/1340/1/012023

James, O. B. (2018). Social foundations in teacher education: A contemporary snapshot. International Journal of Learning, Teaching and Educational Research, 17(1), 166-174. DOI:10.26803/ijlter.17.1.10

Jean, M., Anja, S., \& Clare, K. (2019). International research, policy, and practice in teacher education: Insider perspectives. Springer. DOI:10.1007/978-3-030-01612-8

John, L., \& Mary, L. H. (2016). International handbook of teacher education, 2, Springer. DOI:10.1007/978-981-10-0369-1

Kai, Y., Andrea, L. S., Li, L., \& Huizhong, C. (2012). Tertiary education at a glance: China. Global perspectives on higher education, 24, Center for International Higher Education, Sense Publishers.

Lawrence, I., John, S., Maria, T. T., Glenn, R., Ray, P. \& Sharon, L. S. (2013). An analysis of teacher education context, structure, and quality-assurance arrangements in TEDS-M countries. Australia Council for Educational Research, Michigan State University.

Lee, J.-K. (2000). Main reform on higher education systems in Korea. Revista Electrónica de Investigación Educativa, 2(2), 61-76.

Lixu, L. (2004). China higher education reform 1998-2003: A summary. Asia Pacific Education Review, 5(1), 14-22.

Lu, L. Z., Anh, B., \& Van, B. (2019). Private universities in Vietnam: Reflection and proposition. International Journal of Learning, Teaching and Educational Research, 18(12), 280-301. DOI:10.26803/ijlter.18.12.16

Michael, A. P. (2018). History of teacher education. In: Peters M.A. (eds), Encyclopedia of educational philosophy and theory. Springer. DOI:10.1007/978-981-287-5884_100484

Oon-Seng, T., Woon-Chia, L., \& Ee-Ling, L. (2017). Teacher education in the 21st century: Singapore's evolution and innovation. Springer. DOI:10.1007/978-981-10-3386-5

Paine, L.W., Fang, Y.P., Wilson, S. (2006). Reform as a hybrid model of teaching and teacher development in China. International Journal for Education Research, 45(4-5), 279-289. DOI:10.1016/j.ijer.2007.02.006 
Paul, R. W. (2015). The teacher workforce in Australia: Supply, demand, and data issues. Australia Council for Educational Research, Policy Insights, 2, Melbourne.

Prakash, C. J. (2014). The need for restructuring teacher education programs in India: An essence for globalization. International Letters of Social and Humanistic Sciences, 34, 21-28.

Quang, H. P. (2013). Developing teacher training curriculum: Theory and practice. Thai Nguyen University Publishing House.

Rita, B. F. (2019). Teacher education and teacher development. Springer. DOI:10.1007/978-3030-11066-6_16

Robyn, B., Kathryn, G., Mellita, J., \& Josephine, R. (2017). Reflective theory and practice in teacher education. 17, Springer. DOI:10.1007/978-981-10-3431-2

Saba, Q., Manal, H., Elham, G. M., Intisar, G., Nasser, A.-D., \& Xiangyun, D. (2020). The impact of teacher preparation programs on professional teaching competencies Female novice teachers' perspectives. International Journal of Learning, Teaching and Educational Research, 19(1), 118-135. DOI:10.26803/ijlter.19.1.7

Sang, Q. P. (2011). Research on building the predictive model to develop tertiary education in Vietnam. Research Project at Ministerial Level, code: B20078-37-31TĐ, The Vietnam National Institute of Educational Sciences.

Sun, Y., \& Zhao, M. (2004). Teacher professional development schools: Exploration, experience, and learning. Research in Teacher Education, 1, 52-65.

Susan, E. E.-J. (2015). Leadership for change in teacher education. SensePublishers. DOI:10.1007/978-94-6209-932-6

Vidovich, L. (2008). Research assessment in Singaporean higher education: Changing educational accountabilities in the context of globalization. International Education Journal, Comparative Perspectives, 9(1), 37-46.

Zhu, X., \& Han, X. (2006). Reconstruction of the teacher education system in China. International Education Journal, 7(1), 66-73. 